\title{
IN SEARCH OF GRADUATE ATTRIBUTES: A SURVEY OF SIX FLAGSHIP PROGRAMMES
}

\section{Winberg*}

Faculty of Education

e-mail: winbergc@cput.ac.za

\section{Bester*}

Curriculum Development Unit

Fundani Centre for Higher Education

Development

e-mail: besterma@cput.ac.za

\section{Scholtz*}

Faculty of Business and Management

e-mail: ScholtzD@cput.ac.za

\section{Monnapula-Mapesela ${ }^{\star \star}$}

Academic Development and Support

e-mail: Imapesela@cut.ac.za

${ }^{* *}$ Central University of Technology

Bloemfontein, South Africa

\section{N. Ronald}

Centre for Quality Promotion \& Assurance

Durban University of Technology

Durban, South Africa

e-mail: normanr@dut.ac.za

\section{J. Snyman}

Higher Education Development and Support

Tshwane University of Technology

Pretoria, South Africa

e-mail: snymanjm@tut.ac.za

\author{
A. Staak* \\ DVC: Teaching and Learning \\ e-mail: staaka@cput.ac.za
}

\author{
S. Sabata* \\ Department of Curriculum Development, \\ Fundani Centre for Higher Education \\ Development \\ e-mail: sabatas@cput.ac.za
}

${ }^{*}$ Cape Peninsula University of Technology

Cape Town, South Africa

\section{R. Sebolao** \\ Academic Development and Support e-mail: rsebolao@cut.ac.za}

\section{Makua}

Teaching and Learning Development Centre Mangosuthu University of Technology

Durban, South Africa

e-mail: makua@mut.ac.za

\section{P. Machika}

Centre for Academic Development

Vaal University of Technology

South Africa

e-mail: paulinema@vut.ac.za

\section{ABSTRACT}

The focus of this study is the emergence of distinctive graduate attributes in flagship programmes at Universities of Technology in South Africa. The theoretical framework chosen for this study, Legitimation Code Theory (Maton 2014), offers an explanation of the underlying knowledge principles that make different kinds of thinking, doing and being possible. This article studies how favourable graduate attributes were achieved, identifies similarities across underpinning structures, and highlights the challenges faced by universities of technology in creating environments in which desired graduate attributes might be developed. The article offers a means of understanding the potential for the emergence of graduate attributes across undergraduate programmes in vocational and professional higher education contexts.

Keywords: graduate attributes, vocational higher education, universities of technology, Legitimation Code Theory. 


\section{INTRODUCTION: GRADUATES IN TURBULENT AND UNPREDICTABLE TIMES}

Higher education is increasingly seen as an important contributor to the South African economy through the production of skilled graduates. This new role has stimulated discussions regarding the knowledge, skills and competencies needed in the $21^{\text {st }}$ century. Graduate attributes are strongly related to universities' missions, visions and values - as well as their accountability for the kinds of students they are producing. With regard to Universities of Technology in South Africa, and career-focussed higher education more generally, concerns have been expressed about student employability and alleged mismatches between graduate attributes and the needs of industry (CHEC 2013). In response to these concerns, South African universities have been required to identify appropriate graduate attributes and implement these across programmes (CHE 2013).

The focus of this article is the attainment of graduate attributes by a number of flagship programmes in the university of technology sector in South Africa. In contrast to many graduate attributes projects that have produced de-contextualised 'wish lists' that are unlikely to be implemented or attained (see e.g., Barrie, Andrews, Dean and Heimanis 2010), this study considered graduate attributes by analysing flagship programmes at universities of technology (i.e. programmes that had already produced notable graduate attributes) and trying to understand the structural and contextual features that enabled the programme and its graduates to attain success in terms of students' academic performance and post-qualification employability. This article is based on work undertaken by the 'Attaining graduate attributes in universities of technology’ project; a three-year study funded by the South African Department of Higher Education and Training through a National Collaborative Teaching Development Grant. The project understands graduate attributes as programme outcomes that emerge from programme inputs - such as levels of academic autonomy, access to resources, world-views, values, curricular selections, sequencing, pacing, and assessment. What is put into a programme is much more likely to influence the graduates that emerge from it than any list of outcomes. All programmes produce graduates with attributes, but the attainment of desired graduate attributes will be dependent on thoughtful and systemic programme inputs.

\section{ATTAINING GRADUATE ATTRIBUTES: A BRIEF OVERVIEW OF THE RESEARCH LITERATURE}

The literature offers a bewildering array of terms such as: generic, core or key competencies and skills; workplace competencies, personal skills, transferable skills, employability skills; professional skills, graduate qualities, generic attributes, generic capabilities, graduate 
capabilities and graduateness. These terms (and others) have emerged as a result of different interpretations by governments, universities and education systems worldwide. Jones $(2001,3)$ points out the need to differentiate between different kinds of graduate attributes, for example, between those linked to: 1) disciplinary knowledge, 2) critical understanding, 3) ethical practices and social responsibilities, and 4) employability and lifelong learning.

The South Africa Council on Higher Education (CHE) understands that graduate attributes are oriented towards different disciplines and fields 'but also encompass values, attitudes, critical thinking, ethical and professional behaviour, and the capacity of a graduate to take what has been learnt beyond the site of learning' $(2013,19)$. It is generally agreed that students need rich and diverse learning opportunities to develop the attributes valued by their universities in support of academic achievement and success beyond the university (Barnett 2006). This requires a shared understanding of graduate attributes by lecturers, managers, students and external stakeholders. Graduate attributes are typically claimed to reflect the collective understandings of the university community in terms of the generic outcomes of a university education (Bond et al. 2017). Bowden and colleagues (2000) define generic graduate attributes as those 'qualities, skills and understandings that a university community agrees its students should develop during their time with the institution’. Research studies, however, indicate that university staff struggle to achieve a common understanding of generically-stated graduate attributes, because these generic statements mean different things in different disciplines. Marton and Booth (1997) showed that university teachers did not share a common understanding of either generic graduate attributes or of the teaching and learning activities that might facilitate their development. Academic staff have different opinions on how graduate attributes are achieved (Jones 2012; Oliver 2013). Much of the literature suggests that academics generally regard graduate attributes initiatives with apathy or even resistance (Holmes 2000) and that even where graduate attributes projects are taken up, their impact is minimal (Fallows and Steven 2000). Thus graduate attributes projects have not generally met with success. While there are cases in which graduate attributes projects have been successful (see e.g. Clark 2005; Hannon 2013) this is relatively rare, partly because of academics' scepticism (Bosanquet, Winchester-Seeto and Rowe 2010), and partly because the skills demanded lack clarity, consistency or a recognisable disciplinary base (Jones 2009; 2012) and largely due to the serious underestimation of the kinds of cultural, institutional and policy change and support required to implement graduate attributes (Green, Hammer and Star 2009). Barrie (2004; 2006) thus recommends moderating institutional claims about graduate attributes. 


\section{CONCEPTUAL FRAMEWORK: TOWARDS A THEORETICAL BASIS FOR GRADUATE ATTRIBUTES}

Graduate attributes are at the heart of higher education, but are under-theorised. As is common in high education policy-making, a technical-rational approach to their implementation has been assumed (Blanco Ramírez 2013; Trowler 2008). 'Technical rationalism’ is a term coined by Donald Schön (1984) to describe management practices that underestimate the role of organisational cultures and the complexity of implementing change. The literature briefly overviewed above issues many warnings about the need for theoretical perspectives that go beyond technical-rational assumptions. Because the achievement of graduate attributes is extremely complex, it was felt that a range of issues needed to be understood: the autonomy of academic staff in curricular decision-making, attitudes towards employability and entrepreneurship, the temporal habitus of the academic staff, as well as curricular processes of selection, sequencing, pacing and assessment. Thus in order to conceptualise the emergence of graduate attributes, we drew on Legitimation Code Theory (LCT) (Maton 2014) because it offers a range of dimensions for analysing underlying principles and practice. We understood that elements work together to enable or constrain the emergence of particular kinds of graduate attributes. Our analysis-uncovered the LCT dimensions of what counts as valued graduate attributes in different flagship programmes at universities of technology and offers a conceptual framework for understanding how desired attributes were attained. The LCT dimensions include:

1. Autonomy (understood in the context of graduate attributes as curricular decisionmaking);

2. Density (attitudes toward the forms of capital that inform different kinds of graduate attributes - such as employability or entrepreneurship);

3. Temporality (the temporal positions and orientations that influence graduate attributes);

4. Semantics (the knowledge structures that enable or constrain particular kinds of graduate attributes);

5. Specialisation (orientations towards knowledge fields and/or people and society that particular graduate attributes might require).

The LCT dimensions are described in more detail below.

\section{Autonomy: Who decides on the curriculum and how does it derive its logic?}

Autonomy has two principal concepts: The first is 'positional autonomy' (PA), which in this 
study refers to the degree of control in curricular decision-making. Control of the curriculum by the academics in charge of the programme, would signal strong positional autonomy (which is coded as PA+ in LCT). If some other authority (either within the institution or outside of it) controls curricular decision-making, then positional autonomy is weakened (PA-). Positional autonomy could be stronger (PA+) or weaker (PA-) along a continuum of strengths. The second concept is 'relational autonomy' (RA) which refers to external influences on the curriculum decision-makers - in particular the principles that underpin the curriculum. Are the principles drawn from the world of science or from the world of practice? If the underpinning principles are derived from academic disciplines, then relational autonomy is stronger $(\mathrm{RA}+)$; if the underpinning principles are influenced by, or drawn from the field of practice then relational autonomy is weaker (RA-), implying that there are stronger external influences on the curriculum (Maton 2005).

\section{Density: What are the material and moral resources that underpin the curriculum?}

Density refers to the material and moral resources or social 'goods' that might be attained by graduates of the programme (related to Bourdieu's (1986) forms of capital). Where there is clear intentionality around employability or entrepreneurial activity, this is described as strong material density $(\mathrm{MaD}+)$; where these attributes are less important this implies weaker material density (MaD-). When a programme has strong ethical guidelines, values or social development imperatives (e.g. a strong social justice mission) this is described as strong moral density $(\mathrm{MoD}+)$, and where the programme or department does not have such clear guidelines, values or imperatives, this is described as weaker moral density (MoD-). It is important to note that the codes imply weaker or stronger imperatives, not the total absence of any material aspirations or the lack of moral values.

\section{Temporality: Is the curriculum inspired by the past, present or future?}

Temporality is the degree to which a programme has a temporal position and orientation. The temporal position describes whether the programme is founded on an established 'old' discipline, such as Physics or Philosophy, or whether it is in a new field, such as Tourism or Web Design. Temporal positions can be more conservative (TP-) or more innovative (TP+). The temporal orientation describes whether the programme is backward-looking or forwardlooking and whether curricular decision-making is more influenced by the past, that is, how things were previously done (TO-), or whether it is more future-looking ( $\mathrm{TO}+$ ), such as preparing students for a workplace of the future. 


\section{Semantics: What knowledge counts?}

There are two continua that describe the knowledge fields that underpin the curriculum: semantic density (SD), or the degree of 'condensation of meaning' (Maton 2014), which is also described as level of intellectual challenge, and semantic gravity (SG), or degree to which meaning 'relates to its context' (Maton 2014), which can also be understood as the complexity of the practice. Semantic density may be stronger (SD+) or weaker (SD-) along a continuum of strengths. Weaker semantic density means that the level of challenge and abstraction is lower; while stronger semantic density means that the level of challenge and abstraction is high. Weaker semantic gravity is less context-dependent, while stronger semantic gravity is more context-dependent. Weakening the semantic gravity in a programme or subject involves drawing generalising principles from the particulars of a specific context or case, while strengthening semantic gravity involves drawing from the world of practice. When there is stronger semantic density (SD+), the abstract, theoretical components of the programme are foregrounded. When there is stronger semantic gravity (SG+) the contextual, practical, workor professionally-oriented aspects of the programme are more dominant. A programme that is described as SD-SG+ does not mean that it is devoid of theory or intellectual challenge; it means that the practical elements are given prominence. Strong semantic gravity can also suggest the complexity of the practice in a particular field.

\section{Specialisation: What is the curriculum's relationship to knowledge and to society?}

The Specialisation codes explain what makes a programme (and its graduates) distinctive. This dimension is based on the premise that every practice, belief or knowledge claim is about something and made by someone, and so sets up an epistemic relation to an object (ER) and a social relation to a subject (SR). Each of the codes may be more strongly or weakly emphasised in practices and beliefs, and these two relative strengths of emphasis together provide the code. Thus, a claim to insight or legitimacy can be viewed as specialised by its epistemic relation, by its social relation, by both, or neither. Emphasis on the epistemic relation (the knowledge relation) (ER+, SR-) suggests that the possession of specialised knowledge, skills or procedures are emphasised as the basis of achievement, while the dispositions of actors are downplayed. On the other hand, a socially-oriented code (ER-, SR+) implies that specialist knowledge or skills are less significant and instead the dispositions of the subject as a knower are emphasised as the measure of achievement. A professional code $(\mathrm{ER}+, \mathrm{SR}+)$ implies that both possessing specialist knowledge and being the right kind of knower is important. Finally, a relativist code 
(ER-, SR-) suggests that neither specialist knowledge nor specific dispositions characterise the programme.

\section{RESEARCH DESIGN AND METHODS}

Applying the LCT dimensions and codes to graduate attributes, required what Maton and Chen (2016) call a 'translation device' to bridge the discursive gap between the theoretical concepts and the research context. In 'translating' the concepts of positional and relational autonomy, material and moral density, and so on into their equivalents in the context of curricular decisionmaking, a number of keywords and descriptors were proposed. Synthesising the five dimensions and the variety of possible positions across the five dimensions, a framework was constructed that shows the dimensions, the associated concepts, the LCT dimension, concepts codes as well keywords and descriptors that we used as a shorthand representation to describe the range of possible positions a programme might occupy.

Table 1: A conceptual framework for understanding graduate attributes

\begin{tabular}{|c|c|c|c|c|}
\hline Dimensions & Concepts & Codes & Keywords & Descriptors \\
\hline \multirow{4}{*}{ Autonomy } & \multirow{4}{*}{$\begin{array}{l}\text { Positional } \\
\text { autonomy } \\
\text { Relational } \\
\text { autonomy }\end{array}$} & $\mathrm{PA}+, \mathrm{RA}+$ & Academic & Academic control \\
\hline & & $\mathrm{PA}+, \mathrm{RA}-$ & Collaborative & Academic 'ownership' \\
\hline & & PA-, RA+ & Resistant & Compliance or resistance \\
\hline & & PA-, RA- & Disempowered & External control \\
\hline \multirow{4}{*}{ Density } & \multirow{4}{*}{$\begin{array}{l}\text { Material } \\
\text { density } \\
\text { Moral density }\end{array}$} & $\mathrm{MaD}+, \mathrm{MoD}+$ & Social entrepreneur & Employability and 'giving back' \\
\hline & & MaD+, MoD- & Entrepreneurial & Entrepreneurial \\
\hline & & MaD-, MoD+ & Social justice & Strong sense of purpose \\
\hline & & MaD-, MoD- & Dependent & No clear sense of purpose \\
\hline \multirow{4}{*}{ Temporality } & \multirow{4}{*}{$\begin{array}{l}\text { Temporal } \\
\text { position } \\
\text { Temporal } \\
\text { orientation }\end{array}$} & $\mathrm{TP}+, \mathrm{TO}+$ & Strategic & Looking for opportunities \\
\hline & & $\mathrm{TP}+, \mathrm{TO}-$ & Traditional & Long standing programme \\
\hline & & TP-, TO+ & Innovative & Inventive, problem-solving \\
\hline & & TP-, TO- & Nostalgic & Backward looking \\
\hline \multirow{4}{*}{ Semantics } & \multirow{4}{*}{$\begin{array}{l}\text { Semantic } \\
\text { density } \\
\text { Semantic } \\
\text { gravity }\end{array}$} & SD+, SG- & Professional & Fundamental professional areas \\
\hline & & SD+, SG+ & Pure disciplines & Underpinning disciplines \\
\hline & & SD-, SG+ & Practical & The field of practice \\
\hline & & SG-, SG- & Generic & Basic or low-level skills \\
\hline \multirow{4}{*}{ Specialization } & \multirow{4}{*}{$\begin{array}{l}\text { Epistemic } \\
\text { relations } \\
\text { Social } \\
\text { relations }\end{array}$} & $\mathrm{ER}+, \mathrm{SR}+$ & Professionalism & Expertise and dispositions \\
\hline & & $\mathrm{ER}+, \mathrm{SR}-$ & Expert & 'Hard' skills basis of expertise \\
\hline & & ER-, SR+ & People-oriented & 'Soft' skills basis of expertise \\
\hline & & ER-, SR- & Relativist & Anything goes \\
\hline
\end{tabular}

Adapted from Maton (2014)

The flagship programmes were identified as exemplary in several internal and external audits and reviews, particularly in terms of meeting institutional targets for students' success and throughput rates and the achievement of research outputs by academic staff. A questionnaire 
survey was developed, based on the LCT dimensions described above and drawing on Maton and Howard's (2016) approach to quantitative research design based on LCT principles. The survey was implemented by an external consultant with the programme participants, that is, the head of department and the academic staff who teach on the flagship programme $(n=95)$. The researchers had access to curriculum documents and in some cases held pre-survey and postsurvey feedback focus group discussions with programme staff. The responses of the programme participants were mapped against the 'distinctiveness grid' to show how graduate attributes might emerge from programme inputs, and to establish programme trends.

\section{RESEARCH FINDINGS: HOW DESIRABLE GRADUATE ATTRIBUTES WERE ACHIEVED}

On most universities' wish lists of graduate attributes one might find descriptors such as 'employable’, ‘entrepreneurial’, ‘innovative’, ‘creative', 'environmentally aware’, 'ethical practitioners' and 'responsible citizens'. In these findings we briefly report on what it took for six flagship programmes to actually achieve some of these qualities in their graduating students.

\section{Case study 1: Flagships in preparing students for an uncertain future}

There can be no more uncertain future to prepare students for than the fickle worlds of the fashion industry and advertising - yet two programmes did just that. Durban University of Technology's National Diploma in Fashion was selected as a programme that was particularly successful in achieving awards for student designs, as well as the success of its graduates in establishing businesses in the competitive fashion industry. Tshwane University of Technology's Diploma in Graphic and Web Design was identified as a flagship for similar reasons; in this case the employment rate for students graduating with the qualification is very high - something fairly unusual in the fast-paced world of advertising and marketing where finding employment is extremely difficult (Kalfa and Taksa 2015). The curricula in both programmes emphasise individual ideas and creativity, but ground these on solid technical skills.

In the case of the fashion diploma, entrepreneurship and business skills are developed across the programme. Practical design and manufacturing processes are complemented by modules on contemporary culture, fashion forecasting, consumer psychology, style and image, fabric awareness, textile design, textile printing - while business studies, marketing and communication are taken at all levels. With regard to the National Diploma in Graphic and Web Design, the curriculum comprises five subjects that are taken to a higher level each year: Communication Design, Design Techniques, Graphic Design Drawing and History, Theory of 
Graphic Design and Professional Graphic Design Practice. The design of the graphic and web design curriculum is built on elements of social sciences, business sciences as well as the field of information and communication technologies. As a result of this, the programme is practically-oriented. The programme has a focus on social entrepreneurship. For example, Indigenous Knowledge Systems are regarded as an important base for addressing financially viable community-based designs. Although specialist knowledge is regarded as the key determinant for student success, good language and inter-personal skills are also regarded as important for working in multi-disciplinary teams. The academics in the Graphic and Web Design department are innovative in their own creative work and in teaching and learning contexts and thus more able to able to prepare students for careers in the rapidly changing creative industries. The department has strong links with design industries, and introduces students to standards set by the world of work by including, for example, industry-based assessors or by inviting professionals to set the design briefs. These industry collaborations are regarded by the academic staff as the most important elements of the programme. The underpinning principles of the two diplomas are summarised in Table 2.

Table 2: Underpinning principles: The Fashion Diploma

\begin{tabular}{|l|l|l|l|}
\hline Dimensions & LCT codes & Keywords & Comments \\
\hline Autonomy & PA+, RA- & Collaborative & $\begin{array}{l}\text { There is academic 'ownership' of the curriculum (i.e., } \\
\text { academic staff develop the programme) but seek input } \\
\text { and formative feedback from design entrepreneurs. }\end{array}$ \\
\hline Density & MaD+, MoD- & Entrepreneurial & $\begin{array}{l}\text { The programme's ethos is that of the 'design } \\
\text { entrepreneur'. }\end{array}$ \\
\hline Temporality & TP-, TO+ & Innovative & The curriculum is future-oriented and innovative. \\
\hline Semantics & SG+, SD- & Practical & $\begin{array}{l}\text { The curriculum is practically-oriented with a base of } \\
\text { creative and technical design subjects. }\end{array}$ \\
\hline Specialisation & ER-, SR+ & People-oriented & $\begin{array}{l}\text { Fashion is strongly people-oriented; a range of personal } \\
\text { dispositions are important for success. }\end{array}$ \\
\hline
\end{tabular}

Table 3: Underpinning principles: The Graphic and Web Design Diploma

\begin{tabular}{|l|l|l|l|}
\hline Dimensions & LCT codes & Keywords & Comments \\
\hline Autonomy & PA+, RA- & Collaborative & $\begin{array}{l}\text { There is academic 'ownership' of the curriculum, but } \\
\text { its logic is derived from the field of practice, thus input } \\
\text { and collaboration is obtained from creative industries. }\end{array}$ \\
\hline Density & MaR+, MoR+ & $\begin{array}{l}\text { Social } \\
\text { entrepreneurship }\end{array}$ & $\begin{array}{l}\text { There is a strong focus on social enterprise, } \\
\text { community-based design projects, etc. }\end{array}$ \\
\hline Temporality & TP-, TO+ & Innovative & The programme is future-oriented and innovative. \\
\hline Semantics & SG+, SD- & Practical & $\begin{array}{l}\text { The curriculum is practically orientated, with less focus } \\
\text { on theory. }\end{array}$ \\
\hline Specialisation & ER-, SR+ & People-oriented & $\begin{array}{l}\text { The curriculum has a strong intention to produce } \\
\text { innovative and creative designers, acting in an ethical } \\
\text { manner. }\end{array}$ \\
\hline
\end{tabular}

There are clear similarities in the underlying principles and practices of both programmes, with the only difference being the focus on business-based entrepreneurship in the fashion diploma and the foregrounding of more socially-aware forms of entrepreneurship in the graphic and web 
design diploma. This is not to imply that the fashion diploma is without social awareness. While design entrepreneurship is a strong focus, many of the design themes are about social justice, sustainability, the environment, etc. Both courses are practical, with subjects focussing on the creativity, technology and business acumen required for the field of practice, and develop increasing levels of complexity that build a language for design.

\section{Case study 2: A flagship in environmental and social responsibility}

The National Diploma in Nature Conservation and Biodiversity at the Cape Peninsula University of Technology was identified as a flagship programme because of the staff and students' commitment to sustainable biodiversity and community development. The subjects studied in this diploma include: Animal Studies, Plant Studies, Regional Ecologies, Conservation Management and Conservation Communication. It thus has a knowledge base in the pure and applied sciences, with strong practical components of field work and projects. The importance of Conservation Communication across the diploma is evidence of the department's commitment to the inclusion of communities in conservation practices and decision-making.

The academic staff are proud of the conservation and biodiversity diploma; they have a strong sense of ownership of the curriculum, but are keenly aware that the logic of their programme is derived from the practice of nature conservation. In this regard the course is practically-oriented, although the practical subjects are built on a scientific base. Practices in nature conservation are knowledge-based and thus require a strong grounding in basic and applied sciences.

In the pre- and post-survey meetings, it emerged that the department had strong community linkages and an issue repeatedly raised was the importance of allocating time for community and stakeholder engagement. Interacting with communities helped the department to identify conservation needs, as well as the difficulties that communities might encounter in the trade-off between economic activity and conservation. The department had to consider how to plan for productive community engagement time with their students, while not underestimating the need for scientific work. The staff themselves balance (or strive to balance) the scientific and social aspects of conservation: in a context of development (and perhaps in all contexts) conservation cannot ignore the communities who will benefit from, or be impacted by, conservation practices. This is core to the National Diploma in Nature Conservation and Biodiversity curriculum.

Staff felt that they did not have adequate laboratory space (partly due to issues arising from consolidating programmes at a multi-site university), but were, nevertheless, working on a variety of projects, with little in the way of funding or resources. The department has a strong 
sense of purpose and direction; this is evident both in the service-learning projects that students undertake, and the academic staff's commitment to working with communities to addressing issues related to conservation practices in the past. Table 4 summarizes the underpinning principles of the Nature conservation and biodiversity curriculum.

Table 4: Underpinning principles: The Nature Conservation and Biodiversity Diploma

\begin{tabular}{|l|l|l|l|}
\hline Dimensions & LCT codes & Keywords & Comments \\
\hline Autonomy & PA+, PR- & Collaborative & $\begin{array}{l}\text { The academic staff take 'ownership' of the curriculum; the } \\
\text { curricular logic derived from the practice of conservation. }\end{array}$ \\
\hline Density & MaD-, MoD+ & Social Justice & There is a strong focus on inclusive nature conservation. \\
\hline Temporality & TP-, TO+ & Innovation & $\begin{array}{l}\text { The programme is strongly future-orientated in addressing } \\
\text { issues related to sustainable biodiversity. }\end{array}$ \\
\hline Semantics & SG+, SD- & Practical & $\begin{array}{l}\text { The practical and applied subjects are supported by a } \\
\text { scientific base. }\end{array}$ \\
\hline Specialisation & ER+, SR+ & Professional & $\begin{array}{l}\text { There is an intention to graduate students who are } \\
\text { innovative problem solvers who work with communities. }\end{array}$ \\
\hline
\end{tabular}

The department's interest is in conservation and community development. Staff engage in 'future talk' with students and their teaching focusses on preparing students to be communityoriented in the practice of nature conservation. Departmental research projects align strongly with their teaching with a focus on addressing sustainable development goals, such as food security, environment and water conservation and poverty alleviation. Such future orientation implies a strong departmental vision and mission.

\section{Case study 3: Flagships in service}

Both the Central University of Technology and the Vaal University of Technology selected their diploma programmes in hospitality management as flagship programmes, largely due to the employability of graduates. Students are required to complete a large number of subjects: Accommodation Management, Hospitality Management, Hospitality Communication, Culinary Studies and Nutrition, Hospitality Information Systems, Hospitality Financial Management, Hospitality Industry Law, Food and Beverage Studies, as well as additional courses in First Aid and a short course in Introduction to Wine. The diploma has a strong practical orientation and includes exposure to work settings and to service-learning opportunities. Although many of the subjects are classroom-based, they are practicallyoriented, that is, they prepare students for the world of hotels and restaurants. From the survey and a study of the curriculum, we characterise the programme's dimensions as shown in Table 5.

The dimensions of the hospitality management diploma that emerge from the curricular and survey data suggest a collaborative approach to programme development, and a strong orientation towards the employability of the graduates. The Central University of Technology 
introduces students to entrepreneurial activity in Hospitality Event Management I (a subject that requires students to plan and run an event and make a profit from it), and support students' participation in community engagement activities outside the classroom. While the course is practically-oriented, staff felt that there was an appropriate level of academic challenge, high professional standards and strict admission criteria. There was ambivalence with regard to whether the programme was conservative or innovative, but all respondents emphasised the importance of taking a long term view in terms of preparing students for the future.

Table 5: Underpinning principles: National Diploma in Food Service Management

\begin{tabular}{|l|l|l|l|}
\hline Dimensions & LCT codes & Keywords & Comments \\
\hline Autonomy & PA+, RA- & Collaborative & $\begin{array}{l}\text { Academic staff and industry partners collaborate } \\
\text { closely in the design of the programme. }\end{array}$ \\
\hline Density & MaD-, MoD+ & Employability & $\begin{array}{l}\text { Educational practices are oriented towards student } \\
\text { employability. }\end{array}$ \\
\hline Temporality & TP-, TO- & Ambivalent & $\begin{array}{l}\text { Staff responses indicated both conservative and } \\
\text { innovative elements. }\end{array}$ \\
\hline Semantics & SG+, SD- & Practical & The programme is practically oriented. \\
\hline Specialisation & ER-, SR+ & $\begin{array}{l}\text { People- } \\
\text { oriented }\end{array}$ & Hospitality management is strongly people-oriented. \\
\hline
\end{tabular}

The Vaal University of Technology's diploma in hospitality management is well established and has been offered for longer than ten years. The programme includes both long-serving staff as well as new young academics who are extremely committed to the programme. The Head of Department and the staff who work in the programme have been recognised as both hospitality and teaching and learning specialists.

\section{Case study 4: A flagship in ethical practice}

The Mangosuthu University of Technology identified four flagship diploma and degree programmes in the accounting department. The programmes were selected because of their innovative leadership with regard to the dynamics of local and global business environments, regular programme revision in conjunction with internal and external structures, (e.g. advisory committees and professional bodies) and extremely consistent staff retention over approximately 10 years. The programmes make use of a variety of teaching approaches, such as face-to-face and on-line modalities, study groups, tutorials and residential academic support. The accounting diploma is highlighted in this case study; it has the following subjects that are taken to higher levels over the three years of the diploma: Economics, Auditing, Financial Accounting, Corporate Law, Public Finance and Accounting, Taxation, and English Communication. The selection of subjects and subject weighting is controlled by the South African Institution of Chartered Accountants (SAICA), thus there is a strong focus on the accountancy disciplines and on the competencies of the graduates with regard to accounting practice. 
Table 6: Underpinning principles: The Accountancy Diploma

\begin{tabular}{|l|l|l|l|}
\hline Dimensions & LCT codes & Keywords & Comments \\
\hline Autonomy & PA+, RA- & Collaborative & $\begin{array}{l}\text { The academic staff have academic autonomy in terms of } \\
\text { curricular decision-making, but there is also strong } \\
\text { professional body control. }\end{array}$ \\
\hline Density & MaD-, MoD+ & Ethical practice & $\begin{array}{l}\text { Ethical accountancy practices are fundamental to the } \\
\text { diploma. }\end{array}$ \\
\hline Temporality & TP+, TO+ & Strategic & The programme is a traditional one, but is future-oriented. \\
\hline Semantics & SG+, SD+ & Expert/practical & $\begin{array}{l}\text { The accountancy diploma foregrounds practice, but the } \\
\text { base discipline of mathematics is extremely challenging. }\end{array}$ \\
\hline Specialisation & ER+, SR+ & Professional & $\begin{array}{l}\text { The diploma aims to produce ethical accountancy } \\
\text { professionals. }\end{array}$ \\
\hline
\end{tabular}

Responses to the questionnaire indicate that there is a high level of programme autonomy despite professional control. Although the programme is not in a new field of study, nor in a field unique to universities of Technology, academic staff are innovative, informed and conscientious about preparing students for the future. The programme has a strong practical focus, but also has the reputation of being challenging and difficult. Although mathematical ability is not a key determinant for student success, hard work, problem solving, critical thinking, good language and inter-personal skills, and a natural talent for the field are needed.

\section{CONCLUSION: EMERGING TRENDS ACROSS THE FLAGSHIP PROGRAMMES}

The main aim of this research was to develop an understanding of how different forms of knowledge might have led to the attainment of desirable graduate attributes. This involved the identification of programme inputs in terms of their LCT dimensions. The most consistent indicator across all programmes was that of Autonomy, in the form of stronger positional autonomy and weaker relational autonomy. This indicates a collaborative dimension in which there is clear academic ownership of a programme that draws its logic from practice or related industries, usually with the collaboration of the external partners. Programme-based collaborations develop over time in order to allow the university department and its external collaborators and advisors to understand and respect one another's different areas of expertise, and to find common ground, in ways that are akin to interdisciplinary collaboration. Such collaborations open up a space for particular graduate outcomes. For example, academic staff in the Nature Conservation and Biodiversity Department enjoy long-standing relationships with the South African National Parks Board, Cape Nature, and the World Wildlife Fund, who play a role in selecting appropriate sites for fieldwork or student internships and provide feedback on the interns. If the university wanted the department to include entrepreneurial graduate attributes as a curricular outcome, for example, the department would have to expand their collaborations and build relationships with 'eco-preneurs' (Isaak 2002). Such collaborations would need time to consolidate before their effects on graduate attributes would be evident. 
Durban University of Technology’s fashion diploma shows how graduate attributes in design entrepreneurship have been carefully nurtured by building relationships within the fashion industry. Their achievement is commendable, particularly as several studies have shown that there is a general absence of appropriate university systems to support entrepreneurial activities and linkages (e.g. Schiller and Brimble 2009). The point we are making is that where spaces exist to build relationships between academics and the wider world, these can be developed in ways that enhance particular kinds of graduate attributes, but that developing these collaborative relationships takes considerable time.

In terms of Density, or resources and positions towards different forms of capital, no clear pattern emerges from the data. Universities of technology have traditionally had a strong focus on the employability of their graduates, and while this is still important, the data suggest some shifts towards entrepreneurship - in the case of the fashion diploma this can be seen quite clearly. The presence of business-type subjects across many of the flagship programmes could provide a space for the development of entrepreneurial thinking, but would need to be tied to the knowledge base. At the post-graduate level (which was not considered in this study) there might be opportunities towards technological entrepreneurship, particularly if supported by strong collaborations across sectors. Many-staff on the flagship programmes are self-reporting to be non-entrepreneurial; this will need further investigation as it is unlikely that students will attain entrepreneurial outcomes if entrepreneurship is not a part of the programme ethos.

Despite student involvement in service learning and other community-based projects, there is not a strong social justice mission emerging from the survey data. A possible reason for this was suggested by Mangosuthu University of Technology respondents who explained that as many students are severely economically disadvantaged, the need for social justice is for the students themselves (as recent \#FeesMustFall student activism has shown). Addressing students' immediate needs, for example, for nutritional support tends to occupy staff in particular locations more than service-learning or community engagement. The Durban University of Technology case study shows that the entrepreneurial ethos of the department not only enabled graduates of the programme to become self-employed as consultants within the fashion and textile industries, as merchandisers, designers, stylists and so on, but also enabled the department to raise its own funds in support of its programme. Thus, in under-resourced university environments there might be a need for more, not less, entrepreneurial activity and the spin-off of such activity is likely to have many benefits.

With regard to temporal positions and orientations the flagship programmes have different histories, traditions, and trajectories - with innovation and innovative problem-solving emerging as a characteristic of most of the flagship programmes, although with many types and 
varieties of innovation evident in the case studies. Innovation is partly in response to resource shortages and solving immediate challenges, rather than in response to market needs but is nevertheless an indicator of a potential contribution to graduate outcomes around innovation. Temporality is a dimension that warrants further exploration. Staff in the case studies were found to be 'future-looking', but our research has not shown how staff came to 'share a vision of the future'. Therefore, a potentially useful curriculum development competence would be the ability to imagine how particular curriculum changes, including graduate attributes, may play out in a future society. One method to help develop this competence is through the use of a type of scenario tool, 'fictive scripting', which is has been successfully developed for technology assessments (Den Boer, Rip and Speller 2009). In short, plausible and dilemma-rich narratives of possible futures are created by small groups of staff. Rather than being used as future roadmaps, these scripts provide staff with an opportunity to engage in reflective enquiry into the future in dedicated workshop spaces. This method has recently been adapted and trialled in curriculum development workshops (Garraway 2017). Analysis of the workshops indicated that the fictive script method did in fact promote reflexivity and learning amongst participants about how curriculum changes made in the present might play out in the future.

In terms of Semantics, or the knowledge fields and disciplines that underpin the flagship programmes, most have a strong practical orientation, but this does not exclude basic sciences or base disciplines that have a high level of academic challenge. The practical orientation is the programme's strength; their focus is the field of practice, rather than the theoretical domain. This is another potential area for supporting particular kinds of graduate outcomes. The knowledge fields of the programme in creative design and technology and the vertical progression of business studies, for example, provide the base for the emergence of the 'design entrepreneur'. The transfer of entrepreneurial skills from the classroom setting to the real world is more likely when there is depth coverage (Souitaris, Zerbinati and Al-Laham 2007), as there is in the fashion diploma. With regard to the hospitality diplomas at the Central University of Technology and the Vaal University of Technology, there are many studies that point out that a single entrepreneurial practical or course is unlikely to achieve entrepreneurial outcomes or attributes. Entrepreneurial theory and practice would need to be consistently embedded across the programme (Hager 2006). The management-based subjects in these diplomas create opportunities for progressive entrepreneurial outcomes to support Event Management practical and create more sustainable entrepreneurial practices. The departments might consider consolidating subjects (particularly where there might be repetition) as there are 14 first year subjects (excluding the Introduction to Wine and First Aid courses). Consolidation would enable a focus on desired graduate attributes. The programme progresses from knowledge of 
the field and practice towards management. As the programme does not take Culinary Studies to a high level it is unlikely that graduates will achieve desirable outcomes in food innovation; innovation arises out of core areas of the programme rather than capstone courses (see e.g. Nabi, Holden and Walmsley 2010).

Most of the flagship programmes include experiential learning components, that is, learning that takes place outside of the university. There was variety in these work placements that relate strongly to the field of practice, for example, fieldwork in nature conversation. These workplaces are the result of long-standing university-industry collaborations, many going back many years. Universities of Technologies' experience in supporting students' learning in contexts other than the university, and particularly the ways in which the flagship programmes integrate theory and practice in work settings, provides opportunities for the emergence of a range of graduate attributes. The accountancy diploma does not place its students in companies as this is a restriction placed by the professional body; the fashion diploma also does not include a work placement - perhaps because the programme is more focused on building entrepreneurial skills than exposing students to work practice in employee roles.

With regard to Specialisation, some programmes have a closer relationship with their knowledge base, such as the diplomas in nature conservation and biodiversity and in accountancy, that is, they have a stronger epistemic relation. Other programmes, such as the diplomas in fashion, graphic design and hospitality management are more socially-oriented, thus have a stronger social relation. Despite these differences, all respondents valued similar graduate attributes (which would be reflected differently in the various fields) and all programmes were trying to produce graduates who were independent, critical thinkers, and innovative problem solvers. A surprising number of respondents did not seem to particularly value 'technologically savvy practitioners' as characterising their graduates. Table 7 summarises the research findings.

The theoretical framework chosen for this study, LCT, offers an explanation of the underpinning principles that made different kinds of graduate attributes possible. By examining the underlying structure of flagship programmes, we have made explicit how graduates' thinking, doing and being emerged from the legitimation codes of the different programmes. Understanding how particular graduate attributes emerge could help academic staff and heads of programmes to understand how programmes that have not yet achieved valued distinctiveness might be assisted to move towards this. This offers the basis for an enhanced understanding of how graduate attributes might be achieved in higher vocational and professional education. 
Table 7: Summary of the research findings

\begin{tabular}{|c|c|c|c|c|c|}
\hline $\begin{array}{l}\text { Research } \\
\text { Findings - } \\
\text { desirable } \\
\text { graduate } \\
\text { attributes } \\
\text { are } \\
\text { attained } \\
\text { when: }\end{array}$ & $\begin{array}{l}\text { Academic staff have } \\
\text { a sense of } \\
\text { 'ownership' of the } \\
\text { programme and } \\
\text { collaborate with } \\
\text { relevant external } \\
\text { groups } \\
\text { (professional } \\
\text { councils, advisory } \\
\text { bodies, etc.). }\end{array}$ & $\begin{array}{l}\text { Academic staff } \\
\text { have a strong } \\
\text { sense of } \\
\text { purpose and } \\
\text { contribution to } \\
\text { the field } \\
\text { ('making a } \\
\text { difference'). }\end{array}$ & $\begin{array}{l}\text { Academic staff } \\
\text { are forward- } \\
\text { looking, } \\
\text { innovative, } \\
\text { engage in 'future } \\
\text { talk' with } \\
\text { colleagues and } \\
\text { students }\end{array}$ & $\begin{array}{l}\text { There are } \\
\text { appropriate } \\
\text { curricular } \\
\text { interventions (and } \\
\text { considerable } \\
\text { curricular 'space') } \\
\text { to support the } \\
\text { attainment of } \\
\text { GAs. }\end{array}$ & $\begin{array}{l}\text { Academic staff } \\
\text { know who their } \\
\text { students are and } \\
\text { are proud of } \\
\text { their } \\
\text { achievements }\end{array}$ \\
\hline $\begin{array}{l}\text { Case } \\
\text { studies } \\
\text { that } \\
\text { exemplify } \\
\text { particular } \\
\text { graduate } \\
\text { attributes }\end{array}$ & ALL & $\begin{array}{l}\text { CPUT: Nature } \\
\text { Conservation } \\
\text { MUT: } \\
\text { Accounting }\end{array}$ & $\begin{array}{l}\text { TUT: Graphic } \\
\text { design }\end{array}$ & $\begin{array}{l}\text { DUT: Fashion } \\
\text { Design }\end{array}$ & $\begin{array}{l}\text { CUT: Hospitality } \\
\text { Management } \\
\text { VUT: Hospitality } \\
\text { Management }\end{array}$ \\
\hline $\begin{array}{l}\text { Questions } \\
\text { to ask }\end{array}$ & $\begin{array}{l}\text { How can academic } \\
\text { staff take greater } \\
\text { ownership of the } \\
\text { programme (inc. } \\
\text { GAs)? }\end{array}$ & $\begin{array}{l}\text { Do academic } \\
\text { staff have a } \\
\text { larger sense of } \\
\text { purpose for the } \\
\text { programme? }\end{array}$ & $\begin{array}{l}\text { Do the academic } \\
\text { staff share a } \\
\text { vision of the } \\
\text { future for their } \\
\text { field? Is this } \\
\text { reflected in the } \\
\text { programme? }\end{array}$ & $\begin{array}{l}\text { Does the } \\
\text { curriculum support } \\
\text { what we are trying } \\
\text { to achieve (inc. } \\
\text { GAs)? }\end{array}$ & $\begin{array}{l}\text { What kinds of } \\
\text { students do we } \\
\text { have; what kinds } \\
\text { of graduates are } \\
\text { we producing? }\end{array}$ \\
\hline $\begin{array}{l}\text { Theoretical } \\
\text { basis: LCT } \\
\text { dimensions } \\
\end{array}$ & Autonomy & Density & Temporality & Semantics & Specialization \\
\hline LCT codes & $\begin{array}{l}\text { Stronger positional } \\
\text { autonomy and } \\
\text { weaker relational } \\
\text { autonomy } \\
\text { (PA+, RA-) }\end{array}$ & $\begin{array}{l}\text { Stronger or } \\
\text { weaker } \\
\text { material } \\
\text { density, but } \\
\text { stronger moral } \\
\text { density; } \\
\text { (MaD+, MoD+ } \\
\text { or } \\
\text { MaD-, MoD+) }\end{array}$ & $\begin{array}{l}\text { Stronger or } \\
\text { weaker temporal } \\
\text { positions, but } \\
\text { stronger temporal } \\
\text { orientation } \\
\text { (TP+, TO+ } \\
\text { TP-, TO+) }\end{array}$ & $\begin{array}{l}\text { Stronger or } \\
\text { weaker semantic } \\
\text { density, but } \\
\text { always stronger } \\
\text { semantic gravity } \\
\text { (SD+, SG+ or } \\
\text { SD-, SG+) }\end{array}$ & $\begin{array}{l}\text { Stronger or } \\
\text { weaker } \\
\text { epistemic } \\
\text { relations and } \\
\text { stronger or } \\
\text { weaker social } \\
\text { relations (at } \\
\text { least one } \\
\text { relation is } \\
\text { always stronger) } \\
\text { (ER+, SR+ or } \\
\text { ER+, SR- or } \\
\text { ER-, SR+) }\end{array}$ \\
\hline
\end{tabular}

The flagship programmes produced graduates with valuable skills to contribute to the South African economy; but they are expected to do even more. In the words of the South African Minister of Higher Education and Training they should be producing graduates who are 'qualified and competent to take up the employment and income generating opportunities that exist, as the economy grows and changes in the future' (DHET 2014). What this study shows is the considerable challenge that such changes in direction pose for programmes that have valued the employability of graduates in particular fields and that have developed curricular arrangements and structures in support of this.

\section{REFERENCES}

Barnett, R. 2006. Graduate attributes in an age of uncertainty. In Graduate attributes, learning and employability, ed. P. Hager and S. Holland, 49-65. Dordrecht: Springer.

Barrie, S. C. 2004. A research-based approach to generic graduate attributes policy. Higher Education 
Research \& Development 23(3): 261-275.

Barrie, S. C. 2006. Understanding what we mean by generic attributes of graduates. Higher Education 51: 215-241.

Barrie, S., J. Andrews, L. Dean and I. Heimanis. 2010. Employability: realising the potential of a university education. In A practical guide to university and college management: Beyond the bureaucracy, ed. S. Brown and S. Denton, 283-302. London: Routledge.

Blanco Ramírez, G. 2013. Studying quality beyond technical rationality: Political and symbolic perspectives. Quality in Higher Education 19(2): 126-141.

Bond, C. H., R. Spronken-Smith, A. McLean, N. Smith, S. Frielick, M. Jenkins and S. Marshall. 2017. A framework for enabling graduate outcomes in undergraduate programmes. Higher Education Research \& Development 36(1): 43-58.

Bosanquet, A., T. Winchester-Seeto and A. Rowe. 2010. Changing perceptions underpinning graduate attributes: A pilot study. In Proceedings from the 33rd HERDSA Annual International Conference: Research and Development in Higher Education: Reshaping in Higher Education, ed. M. Devlin, J. Nagy and A. Lichtenberg (33): 105-117.

Bourdieu, P. 1986. The forms of capital. In Handbook of theory and research for the sociology of education, ed. J. Richardson, 241-258. New York: Greenwood.

Bowden, J., G. Hart, B. King, K. Trigwell and O. Watts. 2000. Generic capabilities of ATN university graduates. Final report to DETYA. Melbourne: Australian Teaching and Learning Committee, Australian Technology Network. http://www.clt.uts.edu.au/ATN.grad.cap.project.index.html

Cape Higher Education Consortium. 2013. Pathways from university to work: A graduate destination survey of the 2010 cohort of graduates from the Western Cape: A Cape Higher Education Consortium (CHEC) Study. http://www.chec.ac.za/files/CHEC\%20Graduate\%20Survey\%20 ABRIDGED\%20WEB.pdf

CHE see Council on Higher Education.

CHEC see Cape Higher Education Consortium.

Clark, B. 2005. Sustaining change in universities: Continuities in case studies and concepts. Maidenhead: Open University Press.

Council on Higher Education. 2013. A Framework for Qualification Standards in Higher Education. Pretoria: Council on Higher Education. http://www.che.ac.za/documents/d000248/

Den Boer, D., A. Rip and S. Speller. 2009. Scripting possible futures of nanotechnologies: A methodology which enhances reflexivity. Technology in Society 31(3): 295-304.

Department of Higher Education and Training. 2014. White Paper for Post-School Education and Training. Pretoria: Department of Higher Education \& Training. http://www.dhet.gov.za/ SiteAssets/Latest\%20News/White\%20paper\%20for\%20post-school\%20education\%20and\%20 training.pdf

DHET see Department of Higher Education and Training.

Fallows, S. and C. Steven. 2000. Building employability skills into the higher education curriculum: A university-wide initiative. Education+ Training 42(2): 75-83.

Garraway, J. 2017. Future orientated approaches to curriculum development: Fictive scripting. Higher Education Research and Development. DOI: 10.1080/07294360.2016.1170765.

Green, W., S. Hammer and C. Star. 2009. Facing up to the challenge: Why is it so hard to develop graduate attributes? Higher Education Research \& Development 28(1): 17-29.

Hager, P. 2006. Nature and development of generic attributes. In Graduate attributes, learning and employability, ed. P. Hager and S. Hollard,17-47. Dordrecht: Springer.

Hannon, P. D. 2013. Why is the entrepreneurial university important? Journal of Innovation Management 1(2): 10-17.

Holmes, L. 2000. Questioning the skills agenda in Integrating Key Skills. In Higher Education, ed. S. 
Fallows and C. Steven, 201-214. London, Kogan Page.

Isaak, R. 2002. The making of the ecopreneur. Greener Management International 38: 81-91.

Jones, J. 2001. Generic attributes: An agenda for reform or control. Changing identities: Language and Academic Skills Conference. http://learning.uow.edu.au/LAS2001/selected/jones_2.pdf

Jones, A. 2009. Re-disciplining generic attributes: The disciplinary context in focus. Studies in Higher Education 34(1): 85-100.

Jones, A. 2012. There is nothing generic about graduate attributes: Unpacking the scope of context. Journal of Further and Higher Education 37(5): 1-15.

Kalfa, S. and L. Taksa. 2015. Cultural capital in business higher education: Reconsidering the graduate attributes movement and the focus on employability. Studies in Higher Education 40(4): 580-595.

Marton, F. and S. A. Booth. 1997. Learning and awareness. Mahwah NJ: Lawrence Erlbaum.

Maton, K. 2005. A question of autonomy: Bourdieu's field approach and higher education policy. Journal of Education Policy 20(6): 687-704.

Maton, K. 2014. Knowledge and knowers: Towards a realist sociology of education. London: Routledge.

Maton, K. and R. T. H. Chen. 2016. LCT in qualitative research: Creating a translation device for studying constructivist pedagogy. In Knowledge building: Educational studies in Legitimation Code Theory, ed. K. Maton, S. Hood and S. Shay, 49-71. London: Routledge.

Maton K. and S. Howard. 2016. LCT in mixed-methods research: Evolving an instrument for quantitative data. In Knowledge building: Educational studies in Legitimation Code Theory, ed, K. Maton, S. Hood and S. Shay, 27-48. London: Routledge.

Nabi, G., R. Holden and A. Walmsley, A. 2010. From student to entrepreneur: Towards a model of graduate entrepreneurial career-making, Journal of Education and Work 23(5): 389-415.

Oliver, B. 2013. Graduate attributes as a focus for institution-wide curriculum renewal: Innovations and challenges. Higher Education Research \& Development 32(3): 450-463.

Schiller, D. and P. Brimble. 2009. Capacity building for university-industry linkages in developing countries: The case of the Thai Higher Education Development Project. Science, Technology \& Society 14(1): 59-92.

Schön, D. 1984. The reflective practitioner: How professionals think in action. London: Basic Books.

Souitaris, V., S. Zerbinati and A. Al-Laham. 2007. Do entrepreneurship programmes raise entrepreneurial intention of science and engineering students? The effect of learning, inspiration and resources. Journal of Business venturing 22(4): 566-591.

Trowler, P. 2008. Cultures and change in higher education: Theories and practices. Universities into the 21st Century. New York: Palgrave Macmillan. 